\title{
A Pragmatic Stylistic Framework for Text Analysis
}

\author{
Ibrahim Abushihab ${ }^{1, *}$ \\ ${ }^{1}$ English Department, Alzaytoonah University of Jordan, Jordan \\ *Correspondence: English Department, Alzaytoonah University of Jordan, Jordan. E-mail: \\ facultyofarts2@yahoo.com
}

Received: September 16, 2014 Accepted: January 16, 2015 Published: January 27, 2015

doi:10.5296/ije.v7i1.7015 URL: http://dx.doi.org/10.5296/ije.v7i1.7015

\begin{abstract}
The paper focuses on the identification and analysis of a short story according to the principles of pragmatic stylistics and discourse analysis. The focus on text analysis and pragmatic stylistics is essential to text studies, comprehension of the message of a text and conveying the intention of the producer of the text. The paper also presents a set of standards of textuality and criteria from pragmatic stylistics to text analysis. Analyzing a text according to principles of pragmatic stylistics means approaching the text's meaning and the intention of the producer.
\end{abstract}

Keywords: Discourse analysis, Pragmatic stylistics Textuality, Fictional story and Stylistics 


\section{Introduction}

Discourse Analysis is concerned with the study of the relation between language and its use in context. Harris (1952) was interested in studying the text and its social situation. His paper "Discourse Analysis" was a far cry from the discourse analysis we are studying nowadays. The need for analyzing a text with more comprehensive understanding has given the focus on the emergence of pragmatics. Pragmatics focuses on the communicative use of language conceived as intentional human action. "Intention" has become the focus of various disciplines; for instance, psychologists study the text producer's intention to guide consciousness of the hearer. Austin (1962) stresses that in uttering a sentence, a speaker is involved in three different acts. First, the locutionary act; i.e. the act of uttering a sentence with certain meaning as shown in the following example:

There are four bulls in that field.

The example may be used to warn a walker who is about to cross a fence or as a statement to a fellow farmer. This is called perlocutionary act. In addition, the speaker may intend to constitute an act of praise, criticism, agreement, frightening, boasting, etc. This is called illocutionary act.

Pragmatics also deals with written or spoken texts in terms of functions of their producers (writers and speakers), receivers (readers and hearers) and contexts. Pragmatics is defined by Crystal (1992) as "the study of the principles governing the communicative use of language, especially as encountered in conversations". (p. 271). Van Dijk (1981: 128) points out that the actual communicative situation is "how speakers and hearers go about planning, executing, understanding, storing in memory, accepting and, in general, changing their minds relative to speech acts". Wodak (2007) assures that within other trends of pragmatics there are also relevant insights about what a hearer does when constructing an ad hoc contextualization while processing an utterance, starting from a "context" in the broad sense and narrowing it down into a set of supposedly useful assumptions. (p. 219)

To sum up, pragmatics mainly focuses on principles of language use, the interactions of the producers (speaker, writer) and receivers (hearer, reader) and the context of the text.

\section{Historical Background of Text Linguistics}

The last thirty years have witnessed the development of research in text linguistics. The traditional approach of text processing focuses on written words as an aid to teaching pronunciation and grammar. Processing a text is merely equal to the teaching of lexical and grammatical sentences. As a reaction against the traditional approach, structuralism focuses on and emphases the basic sentence patterns. Sentences in a text are analyzed under nine basic patterns. (Abushihab , 2008) as follows:

Pattern 1: N Be Adj

Example: Food is good 


\section{Macrothink}

Pattern 2: N Be UN (uninflected word)

Example: The girl is here

\section{Pattern 3: N1 Be N1}

Example: My brother is a dancer

Pattern 4: N In. V (intransitive)

Example: He runs

Patterns 5: N1 Tr. V (transitive) N2

Example: The girl bought a dress

Pattern 6: N1 Tr. V N2 N3

Example: The mother bought the girl a dress

Pattern 7: N1 Tr. V N2 N3

Example: The player chose Ali captain

Pattern 8: NLV (Linking verb) Adj

Example: The acrobat seems young

Pattern 9: N1 LV N1

Example: My brother remained an outstanding student.

Transformational Grammar has an advantage on the structural grammar in interpreting sentences of the same structure, but of different meanings. For example, structural grammar fails to find the distinction between the sentences.

John is easy to please

John is eager to please (Chomsky, 1965)

Because they both belong to the same pattern of $\mathrm{N}+\mathrm{Be}+$ Adjective +infinitive

Nowadays, a text is not seen as a grammatical unit. But many factors are taken into consideration. The most important factors are background knowledge (Anderson and Pearson, 1984), mental processes (Brown and Yule, 1989) and textuality (Beaugrande and Dressler, 1986).

Discourse analysis studies the relationship between language and the contexts in which it is used. Cook (1989: 6) assumes that "a language in use, for communication is called discourse and the search for what gives discourse coherence is discourse analysis." 


\section{Text, Style and Stylistics in Language Theory}

From discourse analysis, we study the term "text" which refers to any passage, spoken or written, regardless the length. Halliday and Hassan (1976: 2) point out that "a text is best regarded as a semantic unit: a unit not of form but of meaning."

Beaugrande and Dressler (1986) state seven standards of textuality. Some of which are intentionality, acceptability and situationality. Intentionality refers to the text producer's attitude. Acceptability is the text receiver's attitude. Situationality covers the factors which make a text relevant to the context.

Enkvist (1964: 28) assures that "the style of a text is a function of the aggregate of the relations between frequencies of linguistic items and the frequencies of the corresponding items in a contextually related norm." Style as defined by Crystal (1992: 332) is "the relations among the participants in a language activity, especially the level formality they adopt (Colloguial, Formal, etc)". Accordingly, style is considered as a function of linguistic items which has a close relation with the study of the functions in language (Pragmatics)

In the beginning of the 1980's, the focus was on functional and sociolinguistic views which led to the emergence of pragmatics. In addition to pragmatics, the speech act theory and discourse analysis were found out to help in analyzing texts and to form up stylistics. The text is considered as a product which exists in the mind as a result of mental processes.

Saussure (1913) considers language as a system constituted by signs which express ideas. There is a relation between the signified (the text) and the signifier (the form). He adds that the signs include words which have two parts: a mark which he calls the signifier and a concept which he calls the signified. Abushihab (2012) states that "the signifier is the sign vehicle; while the signified is the meaning. The signifier is the form that the sign represents whereas the signified is the concept (image) that the form takes". When you think about a tree, the tree is considered as an object.

It is the signified whereas the written form is the signifier which represents the tree as coded culturally to our minds (Sert, 2006: 107)

In the 1970s, Chomsky's Transformational Generative Grammar influenced the definition of style. Throne (1970) and Ohman (1972) were the representative of the Transformational Grammar to stylistic analysis. They stressed the differences between a poet's choice of words/ grammar and underlying grammatical core sentences. For these linguists, a writer's style offered a set of transformational options taken from an underlying base.

\section{Pragmatics and Discourse Analysis}

Pragmatics focuses on principles of language use, the intentions of producers (speaker, writer) and receivers (hearer and reader) and mainly on contexts. Pragmatics and discourse analysis go beyond the structure of the language. Austin (1962) and Beaugrande and Dessler (1986) 
go along this idea by stressing the role of producer's intention to guide the consciousness of the receivers.

Pragmatics as defined by Bulut (1994) is the theory of human action which deals with the theoretical reconstruction of linguistic rules at action level as well as at form and meaning levels. Pragmatics operates with conversational rules that deal with the systematic uses of utterances. The pragmatic theory stresses the speech act theory, the analysis of conversations and cultural differences. Pragmatics and discourse analysis deal with the communicative use of language which is conceived as an intentional human action. Yalcein (1996) summarizes the standards of textuality which relate to pragmatics and discourse analysis as follows: "text processing concerns how occurrences are connected to others; via grammatical dependencies in the textual world "cohesion"; via conceptual dependencies in the textual world "intentionality and acceptability; via the extent to which the occurrences of the presented text are expected vs. unexpected or known vs. unknown "informativity"; via the setting "situationality"; and via the mutual relevance of separate text "intertextuality".

\section{Analysis a Short Story Based on a Pragmatic Stylistic Framework}

Guy. de Manpassant (1850 - 93) is a french novelist of the naturalistic school, a master of the short story. Her short story "The necklace" will next be analyzed according to the pragmatic stylistic framework. A vain pretty woman is married to a poor man who works as a clerk in a government office. She hates her poverty and does not accept her poor situation. She is invited to an official party and she does not want to be the only woman present not wearing jewels. Accordingly, she borrowed an expensive diamond necklace from her friend. When she arrives home after the party, she finds that the necklace is lost. Without telling her friend the truth, she and her husband borrow a large sum of money in order to buy another similar one replacing the lost necklace. Repaying the money takes them ten years of hard work and miserable life. The worry destroys her beauty. She meets her friend again and she tells her that the missing necklace was not made of diamonds at all but was a false one, so all the troubles they face were unnecessary.

This short story will be analyzed in different dimensions: situation, speech acts, value of the text (the author, the reader and the text) and discourse analysis. The first analysis to be done on this short story is the identification of its theme and field of discourse analysis. This story is a model of discourse analysis, written to be read by different readers. The author is involved in conveying his own message whereas the reader is involved in interpreting the events of the story and what is beyond it. The story like others, focuses on the intention and the desire of the author and his beliefs, and it also focuses on the reader's interpretation and understanding.

The following extract from the short story illustrates the illocutionary act of the text:

"she suffered endlessly, feeling herself born for every delicacy and luxury. She suffered from the poorness of her house, from its mean wall, worn chairs and ugly curtains ...... She imagined silent antechambers, warm rooms, vast saloons ..... " (line 12). 
From the extract stated above, the writer intends to convey that you do not need material things to be happy and appearance is not the source of happiness. It will not change anything. As a result, a conflict occurs between Madam Loisel and her husband. He pays his effort to make her satisfied, but she is not satisfied and she does not like her marriage to a little clerk. This is clear from the following extract:

"She let herself be married off to a little clerk in the Ministry of Education." (line 4)

The word "let" refers to her unhappiness with marriage to him. In this short story, the third person author uses literary figures of speech like irony as the following extract shows:

"Wear flowers, he said "They're very smart at this time of the year. For ten Francs you could get two or three gorgeous roses. She was not convinced." (line 93).

The irony is clearly stated in the above extract. She is unhappy of going to the party with natural flowers which stand for delicacy and nature, but her situation is worse than her expectation. She goes to the party with fake necklace which stands for nothing because false necklace symbolizes greed, dishonesty and false desire.

Madam Loisel borrows a false necklace to cope up with the rich whom she envies, but the irony that the loss of the necklace results in her being in bad situation than she was. The illocutionary act of the text occurs when the jeweler tells her:

"you will have a lifetime to enjoy these diamonds". (line 203)

The jeweler wants to say that the necklace will be hers for the rest of her life to enjoy, but the reader knows this is not true because he knows that these diamonds will take her to a miserable life and hardworking for the rest of her life.

To conclude, the intention of the writer is to tell us how life is changeful and easy thing can make our life good or turn it into a despair situation. He also wants to convey that lie is the source of disasters and unpleasant situation. If Madam Loisel and her husband had not lied, they would not have lived in a miserable situation for ten years. The reader also benefits from the events of the story because it gives him an effective advice to be honest, realistic and to tell the truth.

This short story is a coherent text because it achieves a sequence of events within a framework of logical relations and the components of the text are mutually connected within configuration of the ideas.

The title of the story activates the global knowledge configuration. The reader directs his focus of attention towards the frame which is interesting because the real necklace mainly symbolizes for something good. It does not usually entail troubles and unhappiness. Later, the reader realizes that there is a mismatch between his own frame taken from the title and the events of the story. It is essential for the reader to infer, to fill in the gaps and to connect events to make the story coherent. The end of the story is incomplete. It is left open for the reader to interpret. Madam Loisel and the reader may take a lesson that outword appearance and foolish desire only lead to poor understanding of what is really occurring in the life 
around us. A man pays a heavy price for greed and fakeness.

Narrative cohesion occurs through references; that is, anaphoric, cataphoric and exophoric references:

1- Anaphoric reference (backwards): The narrative cohesion of this short story is achieved by reference to context of the text. Crystal (1992:19) states "anaphoric reference is one way of marking the identity between what is being expressed and what has already been expressed." as the following extract shows.

"Madam Forstier went to her dressing - table, took up a large box, brought it to Madam Loisel, opened it and said: choose any dear". (line 104).

2- Cataphoric reference (forwards) it is a linguistic unit referring forward to another unit look at the following extract:

"She was one of those pretty and charming girls, born, as though fate had blundered over her, into a family of artisans". (Line 1).

The author starts her story with the pronoun "she" and this is the best example for cataphoric reference.

3- Exophoric reference (outside) it is linguistic unit referring to another unit outside the text as the following extract shows:

"He went to the police station, to the newspapers, to offer a reward, to the cab components, everywhere that a ray of hope impelled him". (Line 177).

\section{Conclusion}

The discussion about the pragmatic stylistics focuses on the relation between texts and styles as its main objectives of analysis. Text as defined by crystal (1992:350) is "viewed as a physical "product" and "discourse".It is also viewed as a dynamic process of expression and interpretation, whose function and mode of operation can be investigated by using psycholinguistic and sociolinguistic, as well as linguistic techniques".

Van Dijk (1977) focuses on the notion of the text linguistics. He also stresses the inclusion of the interactants (the producers and receivers of the text), the notion of syntax (the linguistic symbols) and semantics (the objects and their sense and reference relation through the linguistic sign).

In the 1980s, functional views led to the emergence of discourse analysis and pragmatics which were beneficial for the analysis of the structural patterns of texts and literary texts. Pragmatics gives its importance as a new issue added to text analysis. As a result, the emphasis is given on speech acts. Austin (1962), Van Dijk (1977) and Hurford and Heasley (1983) were some of other scholars who gave a value to speech acts and appropriateness to text analysis.

The application of pragmatic stylistic framework to fiction stories is carried out in this paper under the light of a set of criteria which are based on the principles of discourse analysis. In 
"the necklace" the fictional story chosen to be analyzed, the author wants to convey the message that false appearance will never change the course of life.

\section{References}

Abushihab, Ibrahim. (2008). Text Processing and Topic Unity. Atlas for Studies and Research, 3(I).

Abushihab, Ibrahim. (2012). A Semiotic - Based Approach as an Effective Tool for Teaching Verbal and Non - Verbal Aspects of Language. Journal of Language Teaching and Research, 3(6), 1150-1156. http://dx.doi.org/10.4304/j1tr.3.6.1150-1156

Anderson, R., \& Pearson, P. (1984). A Schema - Theoretic View of Basic Processes on Reading Comprehension. In P.D Pearson (Ed), Handbook of Reading Research, pp. 255 - 317, London: Longman.

Austin, John. (1962). How to do things with words. London: Oxford.

Beaugrande, Robert \& W.U Dressler. (1986). Introduction to Text Linguistics. London: Longman.

Brown, G., \& G. Yule. (1989). Discourse Analysis. Cambridge: CUP.

Bulut, Alev. (1994). A Macro Pragmatic Stylistic Framework for Fictional and Non Fictional Text - Type Identification, Doctoral Dissertation, Gazi University.

Chomsky, Noam. (1965). Aspects of the Theory of Syntax. Cambridge: MIT Press.

Cook, Guy. (1989). Discourse. London: OUP.

Crystal, David. (1992). A Dictionary of Linguistics and phonetics. London: Blackwell publisher.

Enkvist, N.E. (1964). Linguistics and Style. London: OUP.

Halliday, M.A.K., \& R. Hassan. (1976). Cohesion in English. London: Longman.

Harriz, Zellig S. (1952). Discourse Analysis in Language, 28, 1 - 30, 474 - 94.

Hurford \& Heaslay. (1983). Semantics: A Coursebook. Cambridge: CUP.

Ohman, R.M. (1972). Literature as sentences in Essays in Stylistic Analysis (ed. Freeman) London: Methuen.

Saussure, Fredinand de (1913). Course in General Linguistics. London: Fontana.

Sert, Olcay. (2006). Semiotic Approach and its Contribution to English Language Learning and Teaching. Hacetepe Universitesi Egitim Fakaltesi Dergisi, 31, 106-114.

Thorne, J.P. (1970). Generative Grammar and Stylistic Analysis. In J. Lyons (ed.), New Horizons in Linguistics, Harmondsworth, Penguin. 
Van Dijk, T (1981). Towards an Empirical Pragmatics: some social psychological conditions of speech Acts. Philosophica, 27(1), 127-138.

Van Dijk, T. (1977). Text and Context: Explorations in the Semantics of Discourse. London: Longman.

Wodak, Ruth. (2007). Pragmatics and Critical Discourse Analysis, Pragmatics and Cognition: A cross-disciplinary Analysis. Pragmatics and Cognition, 15(1), 203-225. http://dx.doi.org/10.1075/pc.15.1.13wod

Yalcin, G (1994). How A Text Hangs Together, G.U Egitim Fak. Der. Yeni Donem, Sag1 2, SS. 14-28.

\section{Copyright Disclaimer}

Copyright for this article is retained by the author(s), with first publication rights granted to the journal.

This is an open-access article distributed under the terms and conditions of the Creative Commons Attribution license (http://creativecommons.org/licenses/by/3.0/). 